\title{
Comparative analysis of recruitment qualifications of industrial designers in Turkey through undergraduate education programs and online recruitment resources
}

\author{
Onder Erkarslan • Nazife A. Kaya • Ozgün Dilek
}

Published online: 8 April 2011

(C) Springer Science+Business Media B.V. 2011

\begin{abstract}
Although the term "industrial designer" is a well known title, the understanding of industrial design as a profession is still unclear, as evidenced by its application in the sector. In light of this, schools of industrial design should, despite the immense contributions to the sector made by their past graduates, continuously revise their curricula and review their deficiencies to provide a better correlation between their graduates and the needs of the industry. The aim of this study is to ascertain the role of the industrial designer from the perspective of industry by analyzing the specifications stated in job adverts for the recruitment of industrial designers. This study was conducted in three phases. In the first phase, an in-depth literature review was completed. The second phase was dedicated to the identification of the industrial designer in terms of education institutions, and to realize this, the curricula and course contents of industrial design undergraduate programs selected from ten universities in Turkey were analyzed. The third phase was directed towards identifying the profile of the industrial designer from the perspective of industry. Thus, the analyses were made through an investigation of the job opportunities available in the industrial design profession announced in seven major job search websites during the last 4 months of 2009. The results of this study are crucial for all parties involved as they help to satisfy the recruitment expectations of industrial design education, the industry, and the graduates.
\end{abstract}

Keywords Industrial design undergraduate education · Professional identity · Professional perception in Industry · Online recruitment resources

\section{Introduction}

Industrial design, as an integrated profession, spans a wide range of specialties including engineering (technology, techniques, material and processing); ergonomics (operation,

O. Erkarslan $(\bowtie) \cdot$ N. A. Kaya · O. Dilek

Faculty of Architecture, Department of Industrial Design,

Izmır Institute of Technology, Urla, Izmir 35430, Turkey

e-mail: ondererkarslan@gmail.com 
safety, usability, sensation); business (marketing, management, planning, corporate identity); and aesthetics (form, visualization, style). It even includes social, environmental, and cultural issues (Giard 2000; ICSID 2003; IDSA 2003). Design is a creative activity whose aim is to establish the multi-faceted qualities of objects, processes, services and their systems in whole life cycles; design is the central factor of innovative humanization of technologies and the crucial factor of cultural and economic exchange (ICSID 2004). Both product design and engineering are concerned with the planning, development and production of goods. Product designers tend to concentrate on people's needs and on how to produce safe, user-friendly products that can be comfortably adapted to the varying lifestyles of the people who use them. Thus, product designers, focusing on the way in which people live, deal with concept, appearance, performance and human factors that influence design. Engineers, on the other hand, are concerned with details, functionality, performance and production, and tend to concentrate more on the problems of making a product function better for the tasks it is designed to do while optimizing its design for production (Owen 2004). The literature on design education argues that there appears to be a serious gap between the missions of industrial design (ID) programs and the needs of the industry from a general perspective. As design education seems reluctant to move beyond basic aesthetics and form-giving, the balance between theory and practice has become a crucial issue for curriculum development in this discipline (Kolko 2004). Incorporating practice into design education is also an important part of the interrelations with industry. Although various applications concerning relations with industry in education (Erkarslan 1998, 2007, 2010; Boyarski 1998; Çırpanlı and Er 2006; Evyapan et al. 2005) have been widely discussed in the literature, the problem remains one of the fundamental issues in design education.

A primary concern of design educators and professionals is the issue of the competencies of industrial designers, and the quality of the ID graduate is often considered by prospective employers to be subpar (Kaufmann 1998). Furthermore, there exists a gap between what students learn at school and what they are required to do in the field after graduation (Ball 2002; Yeh 2003; Yang et al. 2005).

The concept of design and the employment of designers have become more important as new concepts continue to be introduced in the Twenty-first century. The globalization of today's large and small scale economic market, combined with fierce competition, has required changes in the understanding of production to keep up with the development of technological capabilities. The speed of technological development demands the production of high quality products that are cost effective. This has resulted in marketing and sales challenges and created an intensely competitive environment. To survive in such a competitive environment and to adapt to the prevailing economy, companies must satisfy the explicit requirements and achieve the targeted level of customer satisfaction (Kusiak 1992). To become an internationally effective and preferred company, it is essential the company produce different and always better consumption goods. It is this need that unavoidably leads us to the concept of product quality (Kaya 2008). Even though the competitive process differs between communities, it is obvious that consumer behavior is inclined to take a selective course. The criteria invoked by the changing competitive conditions and by consumer attitudes (i.e., competitiveness of the producer and customer satisfaction, which is protected by law) have become the basic elements that shape the economic structure of the twenty-first century (Vanchan and Macpherson 2008). Surveys reveal that companies willing to enjoy a bigger share in the global market recruit industrial designers not only for aesthetic concerns but also for priorities such as the desire to develop new products, to be more 
innovative, to reflect brand identity, and to expand the diversity of products (Suel 2006). In Turkey in the early 1990s, the influences of the competitive free market became apparent in the field of industrial design, and the demand for designers in primary sectors such as automotive, white goods, electronics, and electrical household appliances increased (Kindi 2007).

Undoubtedly, the problem of the unrecognized role of the industrial designer in Turkey is associated with the fact that the development of the Turkish industry was not concurrent with the development of the industrial design profession (Er et al. 2003; Er 1993). In developed countries, the profession emerged and developed in line with the requirements of the industry; however, in Turkey, the industrial product design profession did not emerge as a necessity but as a consequence of international attempts and compulsory steps taken for the sake of modernization. These international attempts were taken mostly with the initiative of US foreign policies in Turkey as in common with some other developing countries. The new program of US for developing countries aimed at the developing local handicrafts and small industries, and exploring commercial potential of those products in internal and external markets - the US market particularly. The relations between Turkey and ICA (International Cooperation Administration, the forerunner of AID) started in 1955. Within the same years, another international project with UN initiative became influential in the development of industrial design in Turkey. This initiative was the establishment a new technical university in Ankara (known as METU-Middle East Technical University) which opened up the first industrial design department in Turkey. Unfortunately METU could not start education until 1970s, but inspired some other universities as well as the industry (Er et al. 2003). While Industrial Product Design (IPD) education in Turkey proceeds with a rational vision that benefits from technological and scientific developments, difficulties with respect to the employment of design professionals by the industry continue to be an issue.

Some of the studies on IPD and ID education focus on the contents of the curricula, the results derived through changes in the instructional methods, and the comparison of the curricula among various universities. On the other hand, there are a few scientific studies that deal with the perception of industrial design practice in Turkey or the terms of employment of industrial designers by the Turkish industry. Apart from the studies that convey personal experiences and estimations, there are a limited number of studies based on scientific data that examine the subject in light of surveys conducted with the managers of companies that employ designers or with the designers that are employed by those companies (Suel 2006).

Before examining the human resource expectations or requirements of a sector in a given area, one should investigate whether there are professionals trained in that particular area. In other words, it is impossible to deal with the human resource and employment problems in a sector without first addressing the education in that sector. As industrial design is a professional area that has gained worldwide recognition only in the last three or four decades, studies dealing with the relationship between the sector and education are more or less similar. In addition to the problems encountered throughout the world by the non-financial sectors willing to employ industrial designers, which stems from their basic approach to the concept of design, a significant problem arises when the education domain positions itself as independent of the sector. As underlined by the studies conducted in this area, first it must be noted that the design activity is defined differently by the different shareholders in this field. 


\section{Method}

This study aims to compare the demands of the sector with the education models applied in undergraduate programs in the discipline of industrial design or product design in Turkey. There are three major phases in the study:

1. Analysis of job listings

2. Analysis of curricula of ID or PD programs

3. Comparisons and findings

A descriptive research design was used in the phases of data collection and data analyses for making accurate descriptions and verifications as can be seen in the seminal study by Wang (2008). Kai Wang examines the job advertisements posted on four Internet career sites in the People's Republic of China and classifies the qualifications expected of a prospective industrial designer. As a result of this research, Wang evaluates the findings of his classifications and recommends that industrial product design education should be diversified. Wang's study covers a broad range of sub-disciplines under the general title of 'design' such as industrial design, mechanism design and interface design.

Although this study used a methodological approach similar to Wang's with respect to the comparisons of job listing web sites and education institutions, our method is original with respect to the integration of content analyses of curricula at selected universities in Turkey. This study only considered the keyword of 'industrial designer' in the search of job listings as other design-related professions, which Wang searched in his study, are unknown terms in the industry in Turkey and never occur in the job listings.

This study aims to provide a framework of the perceptions of Turkish firms with regards to the industrial design profession. To uncover the reasons why companies recruit industrial designers, the companies' expectations of the industrial designer, and the perception of the industrial design professional in the sector, fifty-four out of sixty-seven job advertisements posted on the websites http://www.kariyer.net, http://www.yenibiris.com, http://www.monster.com.tr, http://www.elemanonline.com, http://www.dexigner.com, http://www.etmk.gov.tr, http://www.iskur.gov.tr in September, October, November and December of 2009 were included in the study. We eliminated those that did not contain sufficient information. The number of job advertisements is scarce because the career websites removed those adverts that were published prior to September, and the demand for industrial designers was low.

Once the necessary information was gathered, we compared the qualifications sought in the advertisements for an industrial designer on the career websites with the qualifications of the potential graduates from the IPD and ID departments. We also evaluated the curricula of the IPD and ID departments from ten Universities that prescribed a four-year study and had graduates through 2009. We also took into consideration the contents of the courses as specified by the departments on their websites. We then notated the differences and the similarities among the curricula and the courses.

For this reason, diploma titles offered by the universities are taken into consideration and only ten universities that offer Bachelor of Arts diplomas in industrial design were included from the original twenty-seven universities. These ten were the only institutions that had produced graduates by the year 2009 when this study was completed. The names of the universities included in the content analysis study are listed below with the opening dates of their IPD and ID departments indicated in parentheses: Mimar Sinan Fine Arts University (MSGSU) (1971), Middle East Technical University (ODTU) (1979), Marmara University (MU) (1985), Istanbul Technical University (ITU) (1993), Yeditepe University 
(YU) (1996), Anadolu University (AU) (1999), Izmir University of Economics (IEU) (2004), Kadir Has University (KHU) (2005), Halic University (HU) (2005) and Dogus University (DU) (2005).

The sixteen universities eliminated from the study include Isı University, TOBB University, Meliksah University, Yasar University, Okan University, Erciyes University, Gebze Institute of Technology, Istanbul Trade University, Osmangazi University, Mersin University, Arel University, Suleyman Demirel University, Atılım University, Bahçesehir University, Gazi University and Izmir Institute of Technology. These universities either did not have undergraduate programs, or they did not accept undergraduate students until after 2007.

The authors are currently working as academics in one of the universities not included in this study. Thus, all curricula were examined objectively and based only on the information as it appeared in the websites.

\section{Description of basic professional concepts}

While the qualifications as described in the job advertisements differ with respect to terminology, verbal expressions and wording from the curricula and goals of the educational programs, efforts were made to find commonalities that express the basic professional concepts, thereby allowing us to compare and contrast the job requirements with the undergraduate university programs. These common points were based on the three categories posited by Cooper and Press (1995) (Fig. 1) and are comprised of courses on "design knowledge", "concept skill" and "contextual understanding". These same three

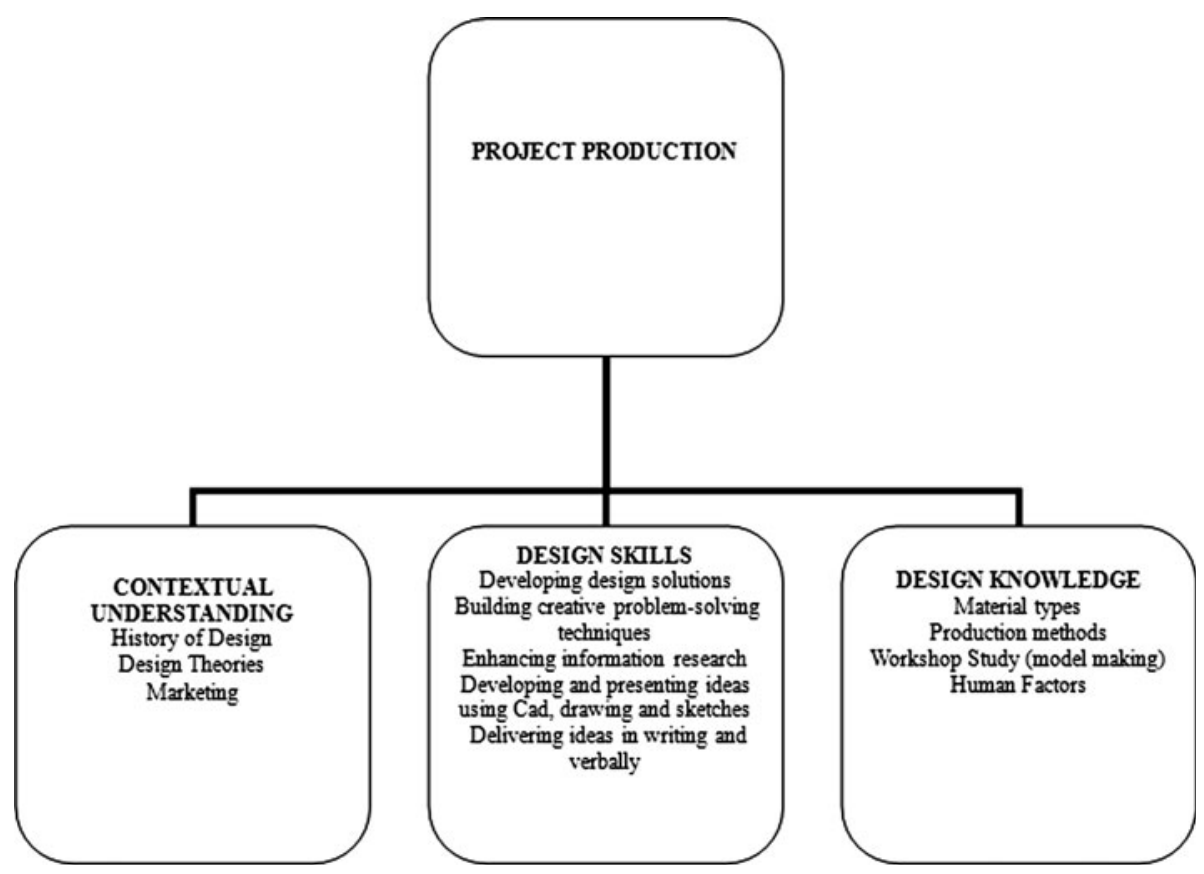

Fig. 1 Design education analysis framework, Cooper \& Press (1995) 
categories correspond to the qualifications that are expressed, albeit using slightly different terminology, in the job advertisements. A framework that allows for the making of comparisons is, thus, obtained.

Because IPD and ID disciplines focus on practice and production, the importance of drawing and technical courses has increased. In this context, "design knowledge" courses are those basic courses that involve the technical knowledge required to produce a project, and the core subjects in the category of design knowledge include materials science, technical drawing, and model making. In "design skills" courses, not only conceptual and technical information is delivered, but production is also practiced. Students become familiar with several disciplines ranging from problem analysis to research and solution. The courses on "conceptual understanding" aim to expand the conceptual world of the design student and to enhance his/her knowledge and productivity in this field. Interdisciplinary courses such as design theories, marketing, and history of design, which invoke new and different ideas within the scope of the project making process for the design student, fall under this umbrella of study.

This classification by Cooper provides an excellent foundation for this study as it allows for the analyses and comparisons of the curricula and job listings using a similar format. For this reason, the authors listed the qualifications that appeared in the job adverts and the contents of the courses in the curricula using the same categories.

\section{Analysis of job advertisements}

After examining the adverts, requisite qualifications for industrial designers were listed and grouped based on similarities. Ten separate qualification categories were identified. Table 1 shows the categories of qualifications found in the job listings and indicates how they correspond to the categories of Cooper \& Press.

In addition to the above categories, three other categories appear on our list that are not specific to the profession of industrial design; rather, they apply to any number of jobs and positions. These categories are:

Table 1 Major qualifications of an industrial designer according to job listings and the corresponding categories of Cooper \& Press

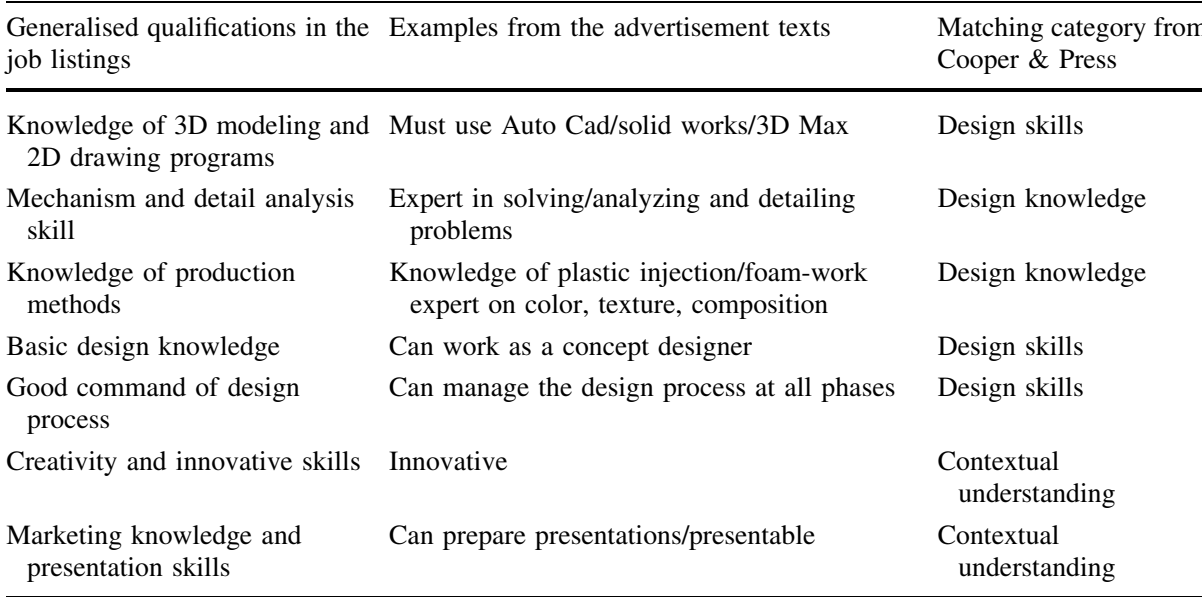


- Experience

- Inclination to Team Work

- Foreign Language

Although these qualifications are demanded by the industry, as evidenced in Fig. 2, they are not directly related to the categories of professional education. Therefore, within this study, these qualifications are considered additional and analyzed independent from the categories of Cooper \& Press. These three categories account for $28 \%$ of the overall qualifications sought by employers in the field of industrial design, while professional qualifications account for $72 \%$ of the desired attributes listed in the job advertisements.

Universities attempt to provide some degree of experience to their graduates by either requiring professional practice through the curricula or by adding life-time learning options. In addition, some universities in Turkey offer diploma programs totally or partially through a foreign language or offer language electives to provide certain advantages to their graduates. Within the last few years, many universities have revised their curricula so that their courses better align with and address the demands of the industry. Furthermore, some universities have incorporated specific courses related to teamwork such as joint workshops. To determine how many universities offer advantages to their graduates in these additional categories, the three additional categories were included in our education analyses.

All qualifications identified in the job advertisements, including the additional categories, were calculated and their weights were determined based on the number of adverts in which each specific qualification was found. As more than one qualification is listed in each advertisement, the findings were converted to percentages that denote the frequency of each qualification within the total, as evidenced in Fig. 2.

Leading the field of those qualifications most desired by employers when looking for industrial designers is cad cam knowledge and skills (Knowledge of 3D Modeling and 2D Drawing Programs) at $85.2 \%$, while $42.6 \%$ of the employers expect the designer to possess
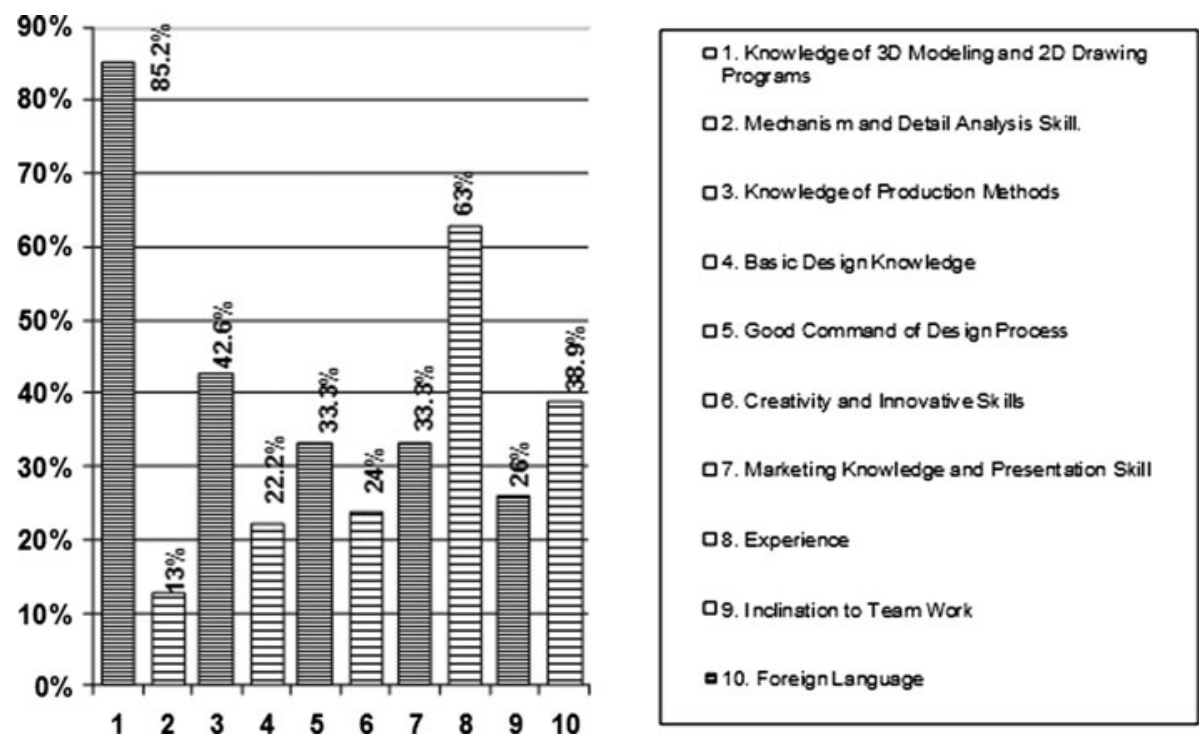

Fig. 2 The frequency for the qualifications sought in job advertisements compared to the total number of advertisements 
specific knowledge related to production methods, particularly as it relates to mold design (Fig. 2). While knowledge of production methods appears to be an important qualification to employers, this attribute, along with three-dimensional modeling programs are, in reality, auxiliary tools for the industrial designer in the new product development process with respect to the realization of the final design. The employer who prioritizes these qualifications over those of creativity and innovation, basic design knowledge, and command of the design process misunderstands the identity and role of the industrial designer.

Employers prefer 'digital representation of the product and knowledge of productionformwork' over 'new product design,' while it is the latter area in which the designer becomes competent during his/her undergraduate education. This suggests that the employer's requirement is not related to design but to production. It further suggests that the employer may perceive the designer as an engineer and/or a technician. It is already known that the industry in Turkey does not contribute to the development of design as expected, favoring a production-oriented development rather than a design-oriented development (Er 1998). Similarly, the marketing and presentation skills found in the advertisements is a reflection of the same minimalist understanding that the designer is expected to establish oneon-one contact with the customer and market the designed product to the customer with an effective presentation. This conclusion is supported by the fact that $33.3 \%$ of the employers are inclined to view the designer as an intermediate employee who enables the company to reach out to the customer. While only $24 \%$ of the employers emphasize creativity and innovative skills, this is an area that design education tries to cultivate in the student. Similarly, only $22.2 \%$ of the employers expect the designer to be competent in basic design elements such as color, form, and texture. The ignorance of the employers about the basic qualifications of the designer suggests that either the company does not perform a true analysis of its requirements or that the job description itself is not properly developed.

In a study conducted by Kindi (2007), findings of the analyses of the qualifications sought in the job advertisements posted on career websites between 2003 and 2006 are consistent with the findings of this study. Kindi also notes that creativity as a qualification was not emphasized in the job advertisements; in fact, Kindi found that some of the job advertisements demanded only computer skills as a qualification. Kindi remarks that the intensity of the implementation and use of innovative, competitive product development components by the industry may be responsible for the overall misconceptions of the profession held by employers.

\section{Analysis of industrial design undergraduate programs in Turkey}

In this section, the Industrial Product Design and Industrial Design courses are divided into three categories and examined (Fig. 1). In this framework, the courses of the Industrial Product Design and Industrial Design Departments of 10 universities that have graduated students through 2009 were compared in terms of their concentrations in these three categories. The industrial design department of Izmir University of Economics divided the program into two specialties, namely, design management and product design. This division is implemented in the fifth term and, as a result, the number of programs studied was eleven. When comparing concentrations, the weekly course hours, which did not represent a coherent distribution in the three categories, were analyzed according to the number of courses covered by the categories (Fig. 3) and the diversity of the courses. As students preferred different electives according to their areas of interest, some of the elective courses, though they appeared in the program, were never opened. Taking this into 


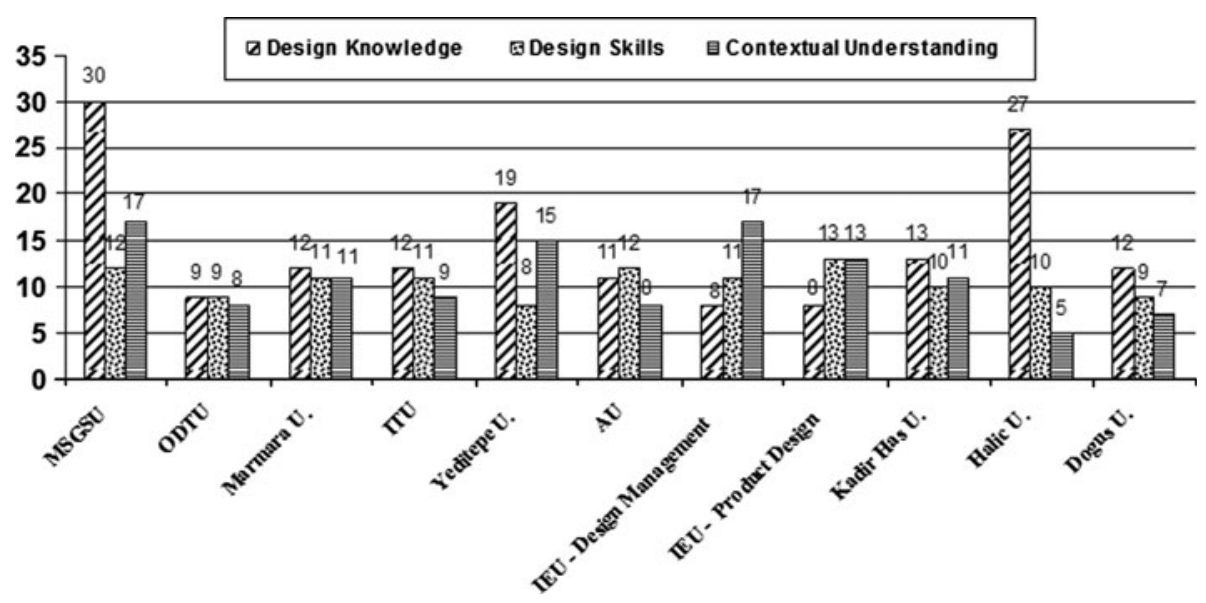

Fig. 3 The graph reflects the number of courses in compulsory categories in IPD and ID departments

consideration, the analyses of the education programs of the Industrial Product Design and Industrial Design Departments of the ten universities that were selected for the study were limited to compulsory courses.

When percentage distribution (Fig. 4) is considered, the universities that give significant weight to 'design knowledge' are MSGSU, MU, YU, KHU, HU, and DU. The other four universities admit students according to quantitative scores on the Student Selection Exam (SSE). The distributions of course categories at ODTU and ITU that accept students according to SSE scores are proximate to each other. While the AU program concentrates on the 'design skills' category, the IEU Product Design program divides the concentration between 'design skills' and 'contextual understanding' courses. The IEU Design Management program gives weight to the 'contextual understanding' category as it more closely aligns with management courses than it does with design practice.

The number of courses in the 'design knowledge' category is higher at MSGSU than at the other universities. The Design-geometry course, which is taught in the first two terms at MSGSU, is also found in the programs at $\mathrm{HU}$ and MU. This is a distinctive course aimed at describing the designed objects on a geometrical plane. The 'computer-assisted design' course, which enables one to create designs in the computerized environment and which is a qualification highly sought in the job market, is taught for six terms at MSGSU and YU and for five terms at $\mathrm{HU}$, while other universities teach this course for one or two terms. The 'detail analysis' course, which has been customized to improve detail analysis competency - a skill expected of the industrial designer by employers, is virtually observed at $\mathrm{AU}$ but is also offered under different course titles at other universities.

While the 'design skills' category is similar at all universities in our study, the IPD and ID departments reside in a number of overarching schools within the universities including the Faculty of Architecture, Faculty of Fine Arts, School of Advanced Studies in Industrial Arts or the Faculty of Design and Arts. During the first two terms in which the basics of design are taught, ODTU, ITU, AU, and HU offer a course titled basic design/design principles, whereas YU, KHU and MU deliver basic art education. IEU and DU deliver this same course under the title art and design. On the other hand, MSGSU teaches both basic art and basic design. Product development courses where methods of innovative 


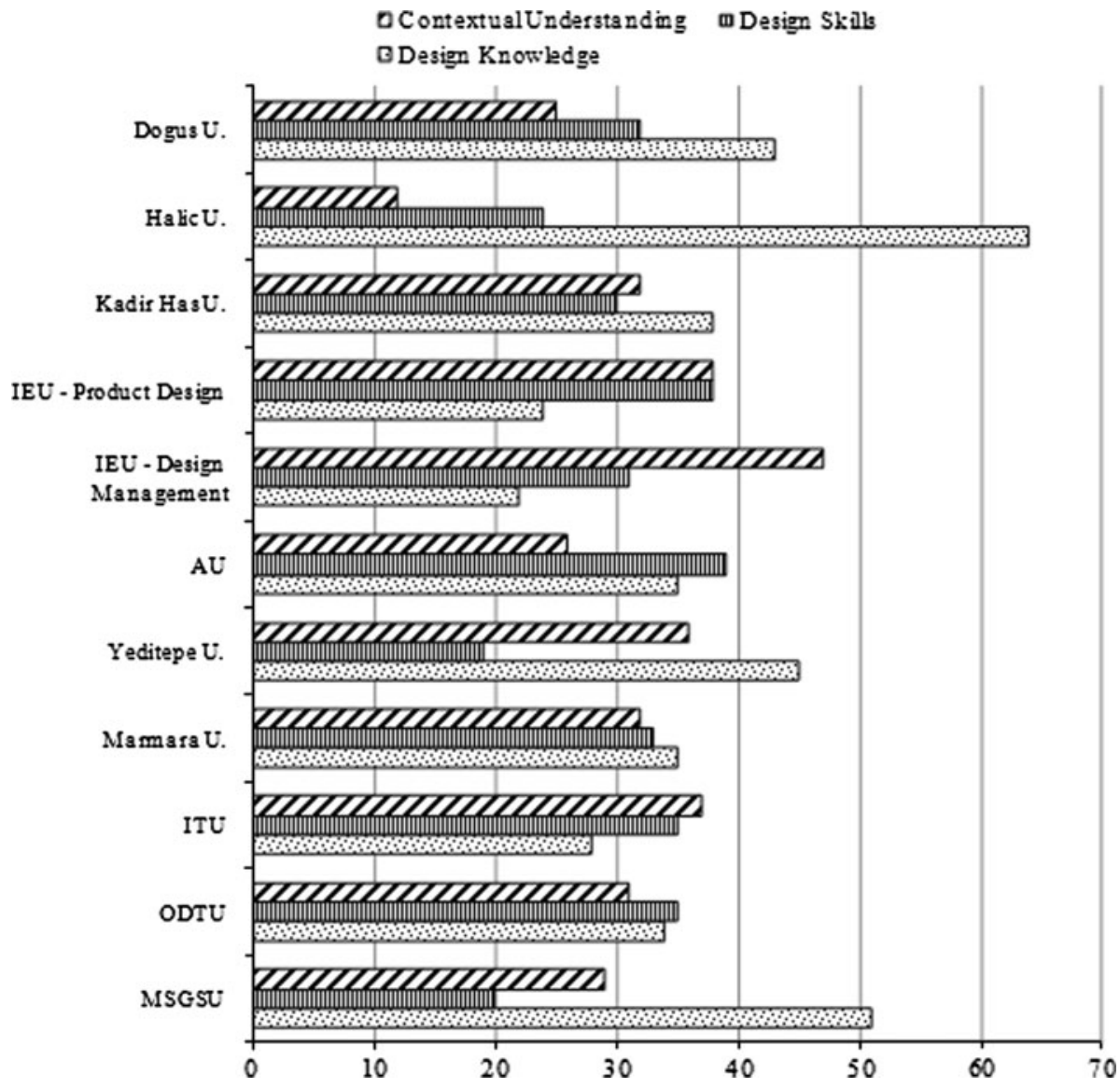

Fig. 4 The graph reflects the percent distribution of compulsory courses in IPD and ID departments

product design are researched are only available at ITU and KHU. Courses dedicated to portfolio presentations, a qualification stressed by employers, are only available at ODTU, IEU, and AU.

'Contextual understanding' courses are important in that they teach the student the methods to pursue when problem solving and help the student to build an intellectual foundation for projects and to comprehend the professional identity of the industrial designer. The Design Management department of IEU has the highest rate of 'conceptual understanding' courses among the eleven departments. These courses guide the student to become much more business- and management- oriented. Courses such as dissertation and research methods, which are included in the 'design skills' category, aim to prepare the students for academic life and are available at MU and IEU. Courses such as trend management, design management, project management, and contemporary topics in design, which enhance awareness of the present and are in communication with the field of design management, are contextual understanding courses that many universities have already included in their curricula as compulsory courses. Design in digital medium, a 


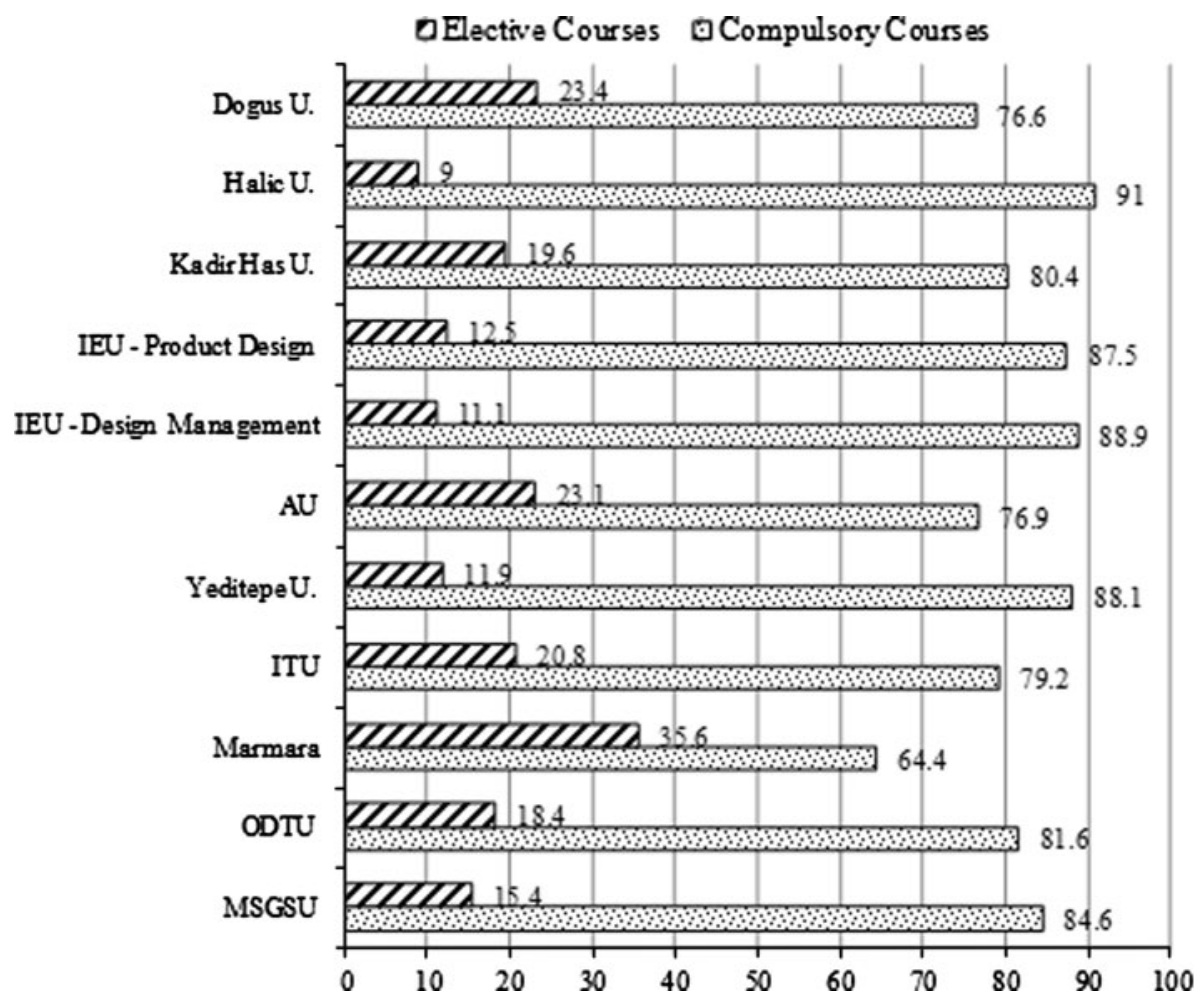

Fig. 5 The graph reflects the percent distribution of the minimum number of elective courses and compulsory courses in IPD and ID departments

course that is only taught at MSGSU, is an innovative course where digital media theories and their applicability to design are discussed.

When the courses were analyzed (Fig. 5), it was found that the compulsory courses, which differed in terms of number of credits, were aimed at improving 'design skill,' whereas elective courses were aimed at improving 'contextual understanding' in addition to design skills, as evidenced in Fig. 6. It is important to note that Izmir Economy University offers the same set of electives for both programs. For this reason, the IEU product design and Design Management programs were analyzed under the same title as IEU during the analysis of the elective courses.

It is also necessary to assess to what degree the PD and IPD programs in Turkey are responding to the issues of foreign language, experience and teamwork. Turkish universities vary in their policies with respect to foreign language education. Some universities prefer to offer all courses in a foreign language, while others only offer electives in a foreign language. Compulsory foreign language courses are generally offered for the technical use of that language. As evidenced in Table 2, five out of eleven programs provide courses in English. Four universities continue to educate in the Turkish language, whereas one university offers its program partially in English. As foreign language education is a highly demanded qualification by the industry, the universities seem to respect 


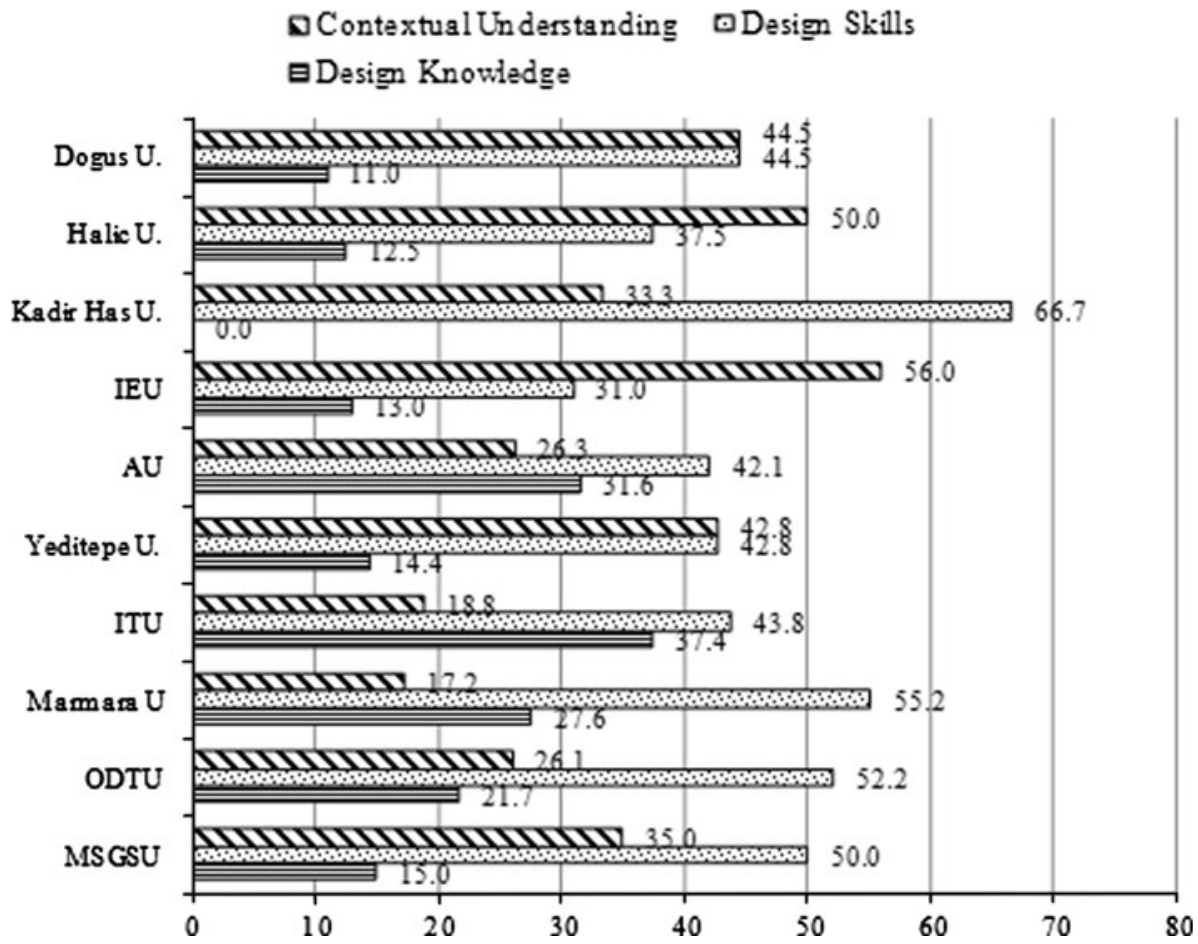

Fig. 6 The graph reflects the percent distribution of elective courses in IPD and ID departments

Table 2 ID and PD programs according to foreign language training

\begin{tabular}{|c|c|c|c|c|c|}
\hline $\begin{array}{l}\text { Name of the } \\
\text { University }\end{array}$ & $\begin{array}{l}\text { Partially in } \\
\text { English }\end{array}$ & $\begin{array}{l}\text { Completely in } \\
\text { English }\end{array}$ & $\begin{array}{l}\text { Completely in } \\
\text { Turkish }\end{array}$ & $\begin{array}{l}\text { Compulsory } \\
\text { foreign languages }\end{array}$ & $\begin{array}{l}\text { Elective foreign } \\
\text { languages }\end{array}$ \\
\hline Dogus University & & $\boldsymbol{\nu}$ & & & $\boldsymbol{V}$ \\
\hline Haliç University & & & $\boldsymbol{V}$ & & $\checkmark$ \\
\hline Kadir Has University & $\checkmark$ & & & & $\checkmark$ \\
\hline IEU Product Design & & $\checkmark$ & & $\boldsymbol{V}$ & \\
\hline IEU Design Management & & $\checkmark$ & & $\checkmark$ & \\
\hline $\mathrm{AU}$ & & & $\checkmark$ & $\boldsymbol{v}$ & $\checkmark$ \\
\hline Yeditepe University & & $\checkmark$ & & & $\checkmark$ \\
\hline Marmara University & & & $\checkmark$ & & \\
\hline ITU & & $\checkmark$ & & & $\checkmark$ \\
\hline ODTU & & $\checkmark$ & & & $\boldsymbol{v}$ \\
\hline MSGSU & & & $\checkmark$ & & $\checkmark$ \\
\hline
\end{tabular}

this requirement in their curricula. Table 2 shows language training options at the selected universities.

With respect to providing experience, courses such as seminar, professional practice, and application workshop for industrial design can be considered important courses that 
Table 3 ID and PD programs according to their opportunities for experience and their emphasis on teamwork

\begin{tabular}{|c|c|c|}
\hline Name of the University & Practice requirements & Teamwork encouragement \\
\hline Doğuş University & No information available & No information available \\
\hline Haliç University & $\checkmark$ & - \\
\hline Kadir Has University & No information available & No information available \\
\hline IEU Product Design & $\boldsymbol{V}$ & $\checkmark$ \\
\hline IEU Design Management & $\checkmark$ & $\checkmark$ \\
\hline $\mathrm{AU}$ & $\checkmark$ & $\checkmark$ \\
\hline Yeditepe University & No information available & No information available \\
\hline Marmara University & $\checkmark$ & - \\
\hline ITU & $\checkmark$ & $\checkmark$ \\
\hline ODTU & $\boldsymbol{v}$ & $\checkmark$ \\
\hline MSGSU & $\boldsymbol{\nu}$ & $\checkmark$ \\
\hline
\end{tabular}

address this area as various designers from the business world are invited to share their experiences or are used as subjects for research. IEU, ODTU and YU have included these courses in their curriculums. These types of opportunities offered by the universities also provide valuable advantages to their graduates with respect to employment preparation as many employers seek candidates who have experience and who possess a desire for working as part of a team. Table 3 shows that the majority of the universities include summer practice requirements for graduation as well as courses that emphasize teamwork.

\section{Findings of the study}

Qualifications sought in the job advertisements analyzed within the scope of this study were assigned to course categories as depicted in Fig. 7. This analysis is made by transforming the rough data with respect to job listing categories as shown in Fig. 2. As each job advertisement includes more than one qualification, Figs. 2 and 9 show the frequency of the specific quality, whereas Fig. 8 shows the percentages of the categories represented in the qualities sought by employers. Based on the graph, $85.2 \%$ of the listings identify design knowledge as an important qualification, while $51.8 \%$ of the employers seek candidates who also possess a contextual understanding of design. Least important among the three categories is design skill, which was listed in only $44.4 \%$ of the advertisements.

The compulsory courses of the Industrial Product Design and Industrial Design departments of the ten universities included in the study are presented in Fig. 4 in terms of percentage distribution by course categories. If the graph is examined in terms of the importance attached to the course categories by the universities and the fields they desire to specialize in, it becomes evident that the percentages are quite different.

A comparison of Figs. 4 and 7 reveals that the education programs that reflect a distribution closest to the qualification percentages sought by employers are used by the universities that give much weight to 'design knowledge' courses. While 85.2 out of a hundred employers absolutely require 'design knowledge', 44.4 and 51.8 out of one hundred employers attach importance to 'design skill' and 'conceptual understanding' qualifications, respectively. Each graduate of the ten universities possesses all of these qualifications though in varying degrees. It is astonishing that only $44.4 \%$ of the employers 
Fig. 7 Frequency of qualification categories sought in job advertisements by course categories

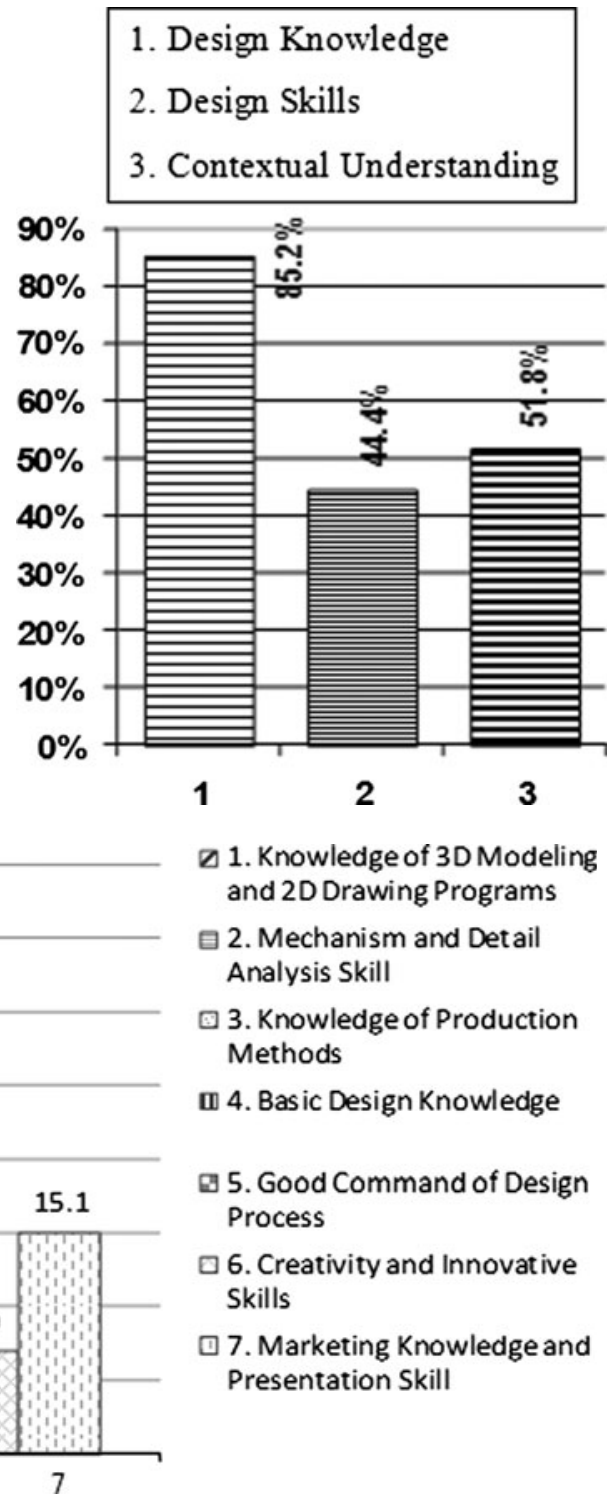

2. Design Skills

3. Contextual Understanding

1. Knowledge of 3D Modeling
2. Mechanism and Detail Analysis Skill

3. Knowledge of Production 4. Bas ic Design Knowledge

5. Good Command of Design

6. Creativity and Innovative 7. Marketing Knowledge and Presentation Skill

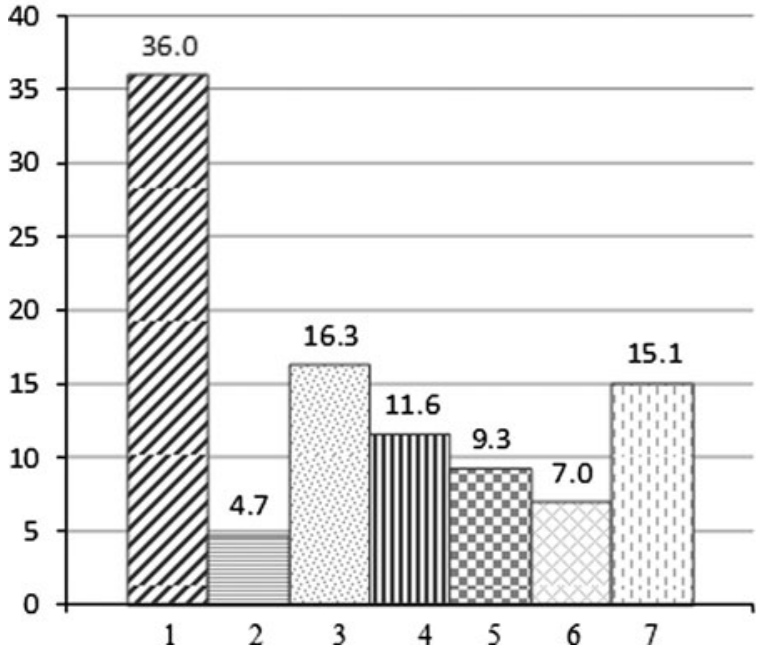

Fig. 8 Percentages of the qualification categories sought in job advertisements by course categories

require the skills and knowledge that are acquired through the 'design skills' courses. This result clearly reveals that the industrial designer is not used efficiently by the employer.

\section{Conclusion}

Qualifications sought in job advertisements for industrial designers published in the last 4 months of 2009 and the curricula for industrial design education programs of ten 


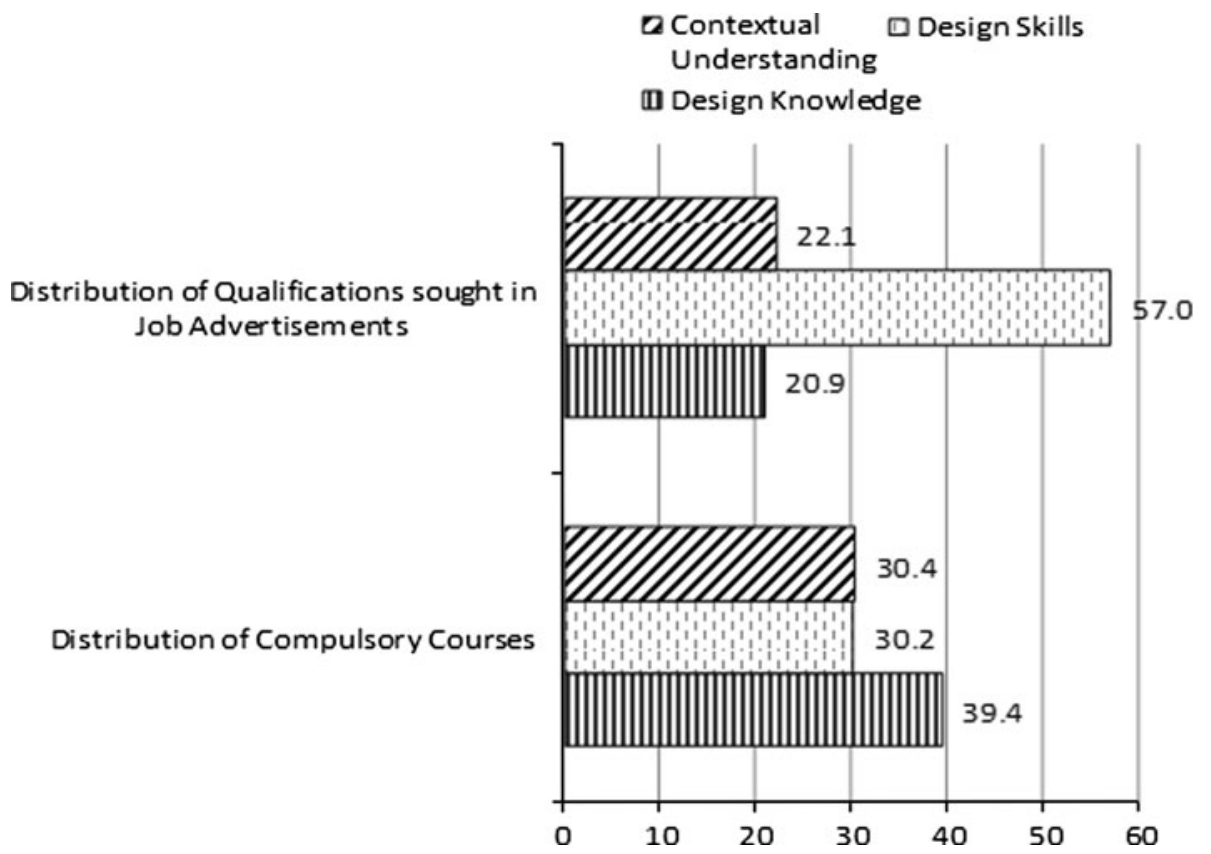

Fig. 9 The graph reflects a comparison of job advertisements and compulsory courses in IPD and ID departments

universities were compared for two purposes: to establish conformity between the education of a newly graduated designer and the requirements of the market and to identify the employer's perception of a designer. The findings of the comparisons are listed below:

1. As a result of the analysis of the job listings, it was determined that $72 \%$ of the qualifications employers are looking for are professional qualities, whereas $28 \%$ of the qualifications are identified as additional qualities such as experience, teamwork and foreign language. Based on these findings, it is possible to say that industry places greater importance on professional qualities in their employment decisions.

2. When professional qualities sought by employers are analyzed, the results show that design skills are the most important at 57\%; contextual understanding comes in second at $22.1 \%$; and design knowledge is third at $20.9 \%$.

3. When the curricula of the programs are analyzed, we find that elective courses cover only $18.25 \%$ of the overall courses. While the contribution of the elective courses in the formation of the graduate profile is limited, compulsory courses play a significant role in this process. When all compulsory courses are examined, it is determined that the design knowledge category is generally represented in the curricula in different ratios ranging from 22 to $64 \%$; however, the emphasis placed on design knowledge in the industry is only $20.9 \%$. Courses in the design skill category are represented in the curricula in ratios that range between 19 and 39\%, while the expectation of the industry ranks design skills at $57 \%$. Courses in contextual understanding are represented in the curricula in ratios ranging from 12 to $47 \%$, while the expectation of the industry ranks the importance of contextual understanding at $22.1 \%$. These 
results strongly suggest that the expectations of the industry and the educational emphasis in the university programs are extremely incompatible.

4. When elective courses are analyzed, the courses in the design knowledge category are represented in the curricula in ratios between 0 and $37.4 \%$; courses in the category of design skill are represented in the curricula in ratios between 31 and 55.2\%; and courses in the category of contextual understanding category are represented in ratios between 17.2 and 56\%. The number of elective courses offered in design skills is considered remarkable, and it is believed that this emphasis helps to compensate for the identified weakness in this category found in the compulsory courses.

\section{References}

Ball, L. (2002). Preparing graduates in art and design to meet the challenges of working in the creative industries: a new model for work. Art, Design and Communication in Higher Education, 1(1), 10-24.

Boyarski, D. (1998). Education: Designing design education. Special Interest Group on Computer and Human Interaction bulletin, 30(3), 2.

Çırpanlı, T., \& Er, H. A. (2006). Tasarımı KOBİ'lerle Buluşturmak: Türkiye ve İtalya'dan İki Üniversite Sanayi İşbirliği Projesi. In H. A. Er, Ş. Timur, L. N. Ece Arıburun, H. Hümanur Bağlı, A. Oğulcan İlhan, A. Zeki Turan, G. Turan, E. Küçüksayraç, \& A. Ensici (Eds.), III. Ulusal Tasarım Kongresi: Türkiye'de Tasarımı Tartışmak Bildiri Kitabı (pp. 42-59). Istanbul: The Istanbul Technical University Press. Devlet Planlama Teşkilatı (DPT) 9. Kalkınma Planı. (2006). Mükerrer Resmî Gazete, Sayı: 26215.

Cooper, R., \& Press, M. (1995). The design agenda: A guide to successful design management. UK: Wiley.

Er, H. A. (1993). The state of design: Towards an assessment of the development of industrial design in Turkey. METU Journal of Faculty of Architecture, 13(1-2), 31-51.

Er, H. A. (1998). Türkiye'de Endüstriyel Tasarım Eğitimi: Dün ve Bugüne Dair İki Saptama. (Ed.) H.A. Er and Ö. Er, Endüstriyel Tasarım Eğitimi: İTÜ Endüstriyel Tasarım Toplantıları 1998-1999 Bildirileri ITÜ Endüstri Ürünleri Tasarımı Bölümü, Nisan 2004, Istanbul.

Er, H. A., Korkut, F., \& Er, Ö. (2003). US involvement in the development of design in the periphery: The Case History of Industrial Design Education in Turkey 1950s-1970s. Design Issues, 19(2), 17-35.

Erkarslan, O. (1998). Tasarımda Doktora Eğitimi Üzerine Alternatif Öneriler. (Ed.) H.A. Er and Ö. Er, Endüstriyel Tasarım Eğitimi: İTÜ Endüstriyel Tasarım Toplantıları 1998-1999 Bildirileri ITÜ Endüstri Ürünleri Tasarımı Bölümü, Nisan 2004, Istanbul.

Erkarslan, O. (2007). Inter-disciplinary characteristics of design profession: Bridging the gap between design education and industry. Proceedings Designtrain Congress Trailer I, pp. 213-218. Amsterdam, the Netherlands, 10-12 May 2007.

Erkarslan, O. (2010). Comparative analysis of master of industrial design education in Turkey. Design and Technology Education: An International Journal, 15(3), 41-57.

Evyapan, N., Korkut, F., \& Hasdoğan, G. (2005). Implications of collaboration with industry for educational strategies in industrial design: the graduation project course (pp. 137-159). Ankara: METU, Faculty of Architecture Press.

Giard, J. (2000). Industrial design values: focus the toast, not the toaster. The 2000 IDSA National Education Conference (CD ROM).

ICSID (International Council of Societies of Industrial Design). (2003). Available from http://www. icsid.org/.

ICSID (International Council of Societies of Industrial Design). (2004). Available from http://www. icsid.org/.

IDSA (Industrial Designers Society of America) (2003). Available from http://www.idsa.org/.

Kaufmann, J. (1998). Why design education? Infrastructure issues affecting the future of industrial design education. The 1998 IDSA National Education Conference (CD ROM).

Kaya, N. A. (2008). Eskişehir Kent Merkezinde Kullanılan Dış Mekan Fitness Spor Aletlerinin Antropometrik Ölçülerinin Değerlendirilmesi ve Bir Tasarım Önerisi Geliştirilmesi. Anadolu Üniversitesi, Fen Bilimleri Enstitüsü, Endüstriyel Tasarım Anabilim Dalı, Yayımlanmamış Yüksek Lisans Tezi, Eskişehir.

Kındı, M. (2007). Türkiye'de Endüstriyel Tasarım İş Piyasası ve İstihdam Düzeyinde Temel Karakteristikleri. Istanbul Teknik Üniversitesi, Fen Bilimleri Enstitüsü, Endüstri Ürünleri Tasarımı Anabilim Dalı, Yayımlanmamış Yüksek Lisans Tezi, Istanbul. 
Kolko, J. (2004). New Techniques in Industrial Design Education, in [online] the 6th international conference of the european academy of design proceedings, Available from: www.jonkolko. com/projectFiles/writing/ead06_id115_2.pdf, Accessed March 26, 2007.

Kusiak, A. (1992). Concurrent engineering automation, tools and techniques. USA: Wiley-Interscience.

Owen, C. L. (2004). What Is Design? Some Questions and Answers. Illinois Institute of Design white paper. Available from: http://www.id.iit.edu/141/documents/whatisdes.pdf. Accessed 30 March 2011.

Suel, A. B. (2006). Türk Endüstrisinde Firma İçi Çalışan Endüstriyel Tasarımcının Rolü: Üreticilerin ve Tasarımcıların Algıları. Orta Doğu Teknik Üniversitesi, Fen Bilimleri Enstitüsü, Endüstri Ürünleri Tasarımı Anabilim Dalı, Yayımlanmamış Yüksek Lisans Tezi, Ankara.

Vanchan, V., \& Macpherson, A. (2008). The recent growth performance of US firms in the industrial design sector: An exploratory study. Industry and Innovation, 15(1), 1-17.

Wang, K. (2008). Research of the recruiting qualifications of the ID profession and their implication in ID education.Computer-Aided Industrial Design and Conceptual Design, CAID/CD 2008, Kunming, China, pp. 851-854.

Yang, M. Y., You, M., \& Chen, F. C. (2005). Competencies and qualifications for industrial design jobs. Implications for design practice, education, and student career guidence. Design Studies, 26(2), 155-189.

Yeh, W. D. (2003). The demand and the evaluation of industrial design profession from the industries. The 6th. Asian Design Conference (CD ROM). 